\title{
Coulisses
}

Revue de théâtre

1 | Printemps 1990

Varia

\section{Débuts de la Brasserie du Commerce}

\section{Rédaction}

\section{CpenEdition}

\section{Journals}

Édition électronique

URL : http://journals.openedition.org/coulisses/1540

DOI : 10.4000/coulisses. 1540

ISSN : 2546-9460

\section{Éditeur}

Presses universitaires de Franche-Comté

\section{Édition imprimée}

Date de publication : 1 avril 1990

Pagination : 13

ISSN : 1150-594X

\section{Référence électronique}

Rédaction, «Débuts de la Brasserie du Commerce », Coulisses [En ligne], 1 | Printemps 1990, mis en ligne le 04 juillet 2017, consulté le 21 octobre 2019. URL : http://journals.openedition.org/coulisses/ 1540 : DOl : 10.4000/coulisses. 1540

Ce document a été généré automatiquement le 21 octobre 2019

Coulisses 


\section{Débuts de la Brasserie du Commerce}

\section{Rédaction}

1 Le 12 décembre, il était possible de se distraire en se rendant à la Brasserie du Commerce où un jeune comédien, Thierry Mouchotte faisait ses débuts dans une soirée cabaret alliant chansons et sketches de toutes sortes.

2 Ce spectacle fut très apprécié des spectateurs amis :

3 «C'était super, il est drôle, il a du talent, il chante bien, il est génial »

4 «Il fallait le faire. »

5 «Il chante bien, les chansons sont jolies, les sketches sont peut-être un petit peu trop du même type mais c'est pas mal. »

6 Il est à noter que Thierry Mouchotte n'est pas un comédien de métier et lorsqu'on lui demande quel diable l'a poussé à déambuler dans l'espace restreint de la Brasserie, voilà ce qu'il répond :

Mis à part ce côté passion du théâtre, j'ai une profession qui est l'assurance. La Brasserie du Commerce fait partie de mes clients et je me suis proposé de leur faire une petite prestation, c'est un simple hasard.

7 Il semblerait donc que le hasard fasse encore bien les choses, notamment en ce qui concerne le côté chansons dont certaines, signalons-le, furent écrites en commun avec une personne de la famille et mises en musique par un ami.

«Il chante vraiment bien, les chansons sont jolies. »

«Moi personnellement, j'aime moins les sketches, par contre les chansons... »

10 « Il a une très belle voix. »

11 «Il faudra qu'il choisisse, moi je prendrais les chansons »

12 «Il chante bien. »

13 Pour conclure, nous avons demandé à Thierry ce qu'il ressentait à la fin de cette soirée.

L'entrée pour moi, c'était un peu dur ; j'étais un peu coincé, j'étais mal ; le public, je

dirais, était complice. Je me suis fait plaisir ce soir. Je suis très heureux, j'ai envie

d'embrasser tout le monde.

Souhaitons que ce bonheur dure encore de longues années. 


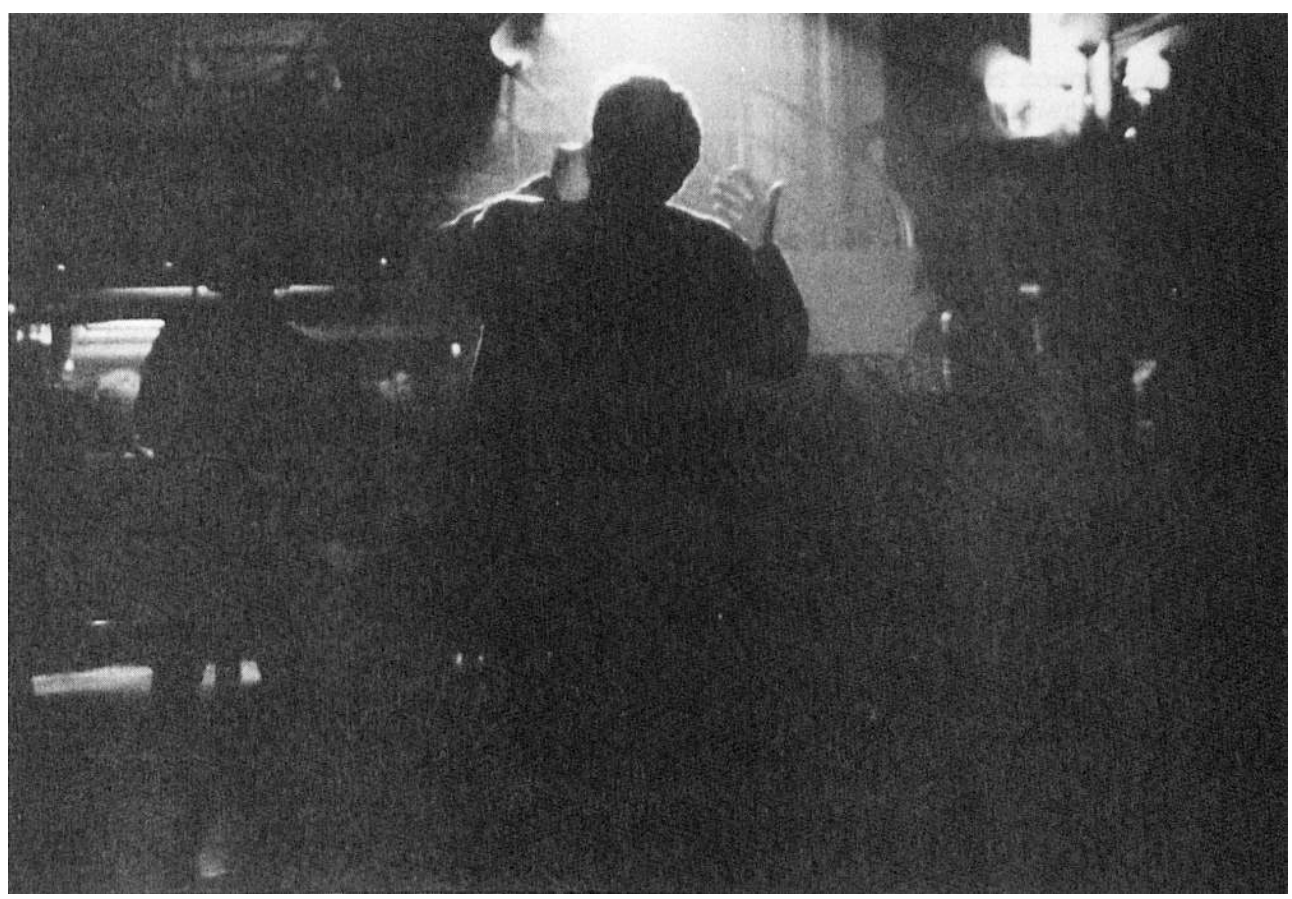

(c) Valérie Goy. 